\title{
Az Alkotmánybíróság fontosabb döntései 2020. január 1-je és június 15-e között
}

\section{SZABÓ ATTILA ${ }^{1}$}

Az Alkotmánybíróság az első félévben 319 döntést hozott, amelyek közül 63 érdemi határozat volt. Az Alkotmánybíróság normakontrollos hatásköreiben három esetben mondta ki jogszabály alaptörvény-ellenességét és semmisitette meg a jogszabályt. A vizsgált időszakban két esetben mondott ki jogalkotói mulasztásban megnyilvánuló alaptörvény-ellenességet és három esetben alkotmányos követelményt. Az Alkotmánybíróság legtöbbet gyakorolt hatásköre továbbra is az alkotmányjogi panaszeljárás, amelyek közül kiemelkedik a bírói ítéletekkel szemben elöterjesztett panasz. Ebben a hatáskörében eljárva az elsö félévben kilenc bírói döntést semmisitett meg.

A cikk hat fontosabb döntést foglal össze a vizsgált időszakból. A 3/2020. (I. 3.) AB határozatban az Alkotmánybiróság az e-cigaretták kiskereskedelmi korlátozásainak alkotmányosságát vizsgálva az érintett vállalkozók kompenzálását irta elö. A becsületsértéssel kapcsolatos 3048/2020. (III. 2.) $A B$ határozatban a véleménynyilvánitás dogmatikáját alakitotta és a közösségi oldalakon közügyekben rendszeresen véleményt nyilvánítókra (úgynevezett influenszerek) fokozottabb türési kötelezettséget állapított meg. A 3049/2020. (III. 2.) AB határozatban az Alkotmánybíróság a vallási szertartás túl hangos végzését csendháboritásnak minösitö bírói döntést vizsgálta. A 3068/2020. (III. 9.) AB határozatban a gyermek jogellenes elvitelével kapcsolatos eljárásban a tisztességes eljáráshoz való jog érvényesülését segitő garanciákat olvasztott ki. A 7/2020. (V. 13.) AB határozatban a közérdekü adatok nyilvánossága védelmében a jogalkotót az adatszolgáltatási kötelezettség elmulasztása esetére hatékony bírói jogvédelem kialakitására hívta fel. Végül a 10/2020. (V. 28.) AB határozatban a megváltozott munkaképességü személyek ellátásaival kapcsolatban állapitott meg a szociális jogokérvényesitését elösegítő alkotmányos követelményt.

\section{Significant Decisions of the Constitutional Court of Hungary between 1 January and 15 June 2020}

The Constitutional Court (hereinafter: CC) made 319 decisions in the first semester of 2020. From these, 63 decisions were on the merits, meanwhile the others were mainly rejections on formal grounds. In the competences of norm control the CC has annulled three legal regulations, it declared three

1 dr., kabinetfőnök, Alkotmánybíróság. 
constitutional requirements and two legislative omissions. The mostly practiced competence of the CC is still the constitutional complaint procedure, mainly the one against judicial decisions. In its competence, the Court annulled nine judicial decisions in the first semester of 2020.

The article summarises six significant decisions of the CC from the first semester of the year. The CC, during the examination of the constitutionality of the statutory limitations on the retail of electronic cigarettes, ruled that a compensation shall be assured by the legislative organ for the entrepreneurs [CC decision 3/2020. (I. 3.) $A B]$. In a case related to libel the Court has formed the case-law on the freedom of speech and established that those publishing opinions on social media in public issues (so called influencers) shall show higher tolerance [CC decision 3048/2020. (III. 2.) AB]. The Court examined a court case based on noise complaint where the petitioner made a religious performance too loudly and the judicial decision claimed it as disturbing the neighbours' peace [CC decision n. 3049/2020. (III. 2.) $A B]$. The Court established certain guarantees in the framework of the right to fair trial in a case launched for wrongful retention of a child 3068/2020. (III. 9.) AB]. The CC has declared a legislative omission in a case for the publicity of public data, calling upon the lawmaker to ensure the effective legal remedy [7/2020. (V. 13.) AB]. In the end, the Court, when examining the regulation on the disability allowances, declared a constitutional requirement in order to provide the allowance for the petitioner, who, previously, had launched a procedure at the European Court of Human Rights. The decision of the CC enables the ordinary courts to interpret the regulations in favour of the complainant [10/2020. (V. 28.) AB].

A)

Az Alkotmánybíróság az első félévben 319 döntést hozott, amelyek közül 63 érdemi határozat, míg 252 - többnyire a befogadási eljárás során hozott - visszautasító végzés. ${ }^{2}$ Az érdemi határozatok - az Alkotmánybíróság hatásköreire figyelemmel - a következők szerint oszlanak meg. Az Alkotmánybíróság 3 esetben utólagos normakontroll indítvány [az Alkotmánybíróságról szóló 2011. évi CLI. törvény (Abtv.) 24. \$-a] alapján járt el. Az Abtv. 25. \$-a szerinti bírói kezdeményezéseket tekintve 12 esetben hozott határozatot. A vizsgált időszakban az Alkotmánybíróság egy esetben az Abtv. 38. $\mathbb{S}$ szerinti hatáskörében az Alaptörvény értelmezését végezte el. Az Alkotmánybíróság legtöbbet gyakorolt hatáskörében, ${ }^{3}$ alkotmányjogi panaszeljárásban 208 esetben járt el, amelyek során összesen 27 érdemi határozatot hozott, amelyből 20 bírói ítélettel

24 ügyben pedig egyesítő végzést hoztak.

32019 első negyedévében az összes kiszignált új ügy 98 volt, amelyből 81 alkotmányjogi panasz. Az előadó alkotmánybíróra kiszignált, befejezett ügyek száma az év első negyedévében 81 volt, amelyből 69 alkotmányjogi panasz. 
szemben előterjesztett panasz volt, 3 pedig közvetlenül a normával szemben előterjesztett panasz.

A határozatok tartalmára tekintettel érdemben a következő határozatok születtek. Jogszabályi rendelkezés alaptörvény-ellenességének megállapítására 4 esetben került sor, ebből 3 esetben az Alkotmánybíróság a jogszabályt megsemmisítette. Bírói döntést 15 esetben semmisített meg. 5 esetben a jogszabály alkalmazási tilalmát mondta ki. Mulasztásban megnyilvánuló alaptörvény-ellenességet egyszer állapított meg, 6 alkalommal pedig alkotmányos követelményt mondott ki. Az indítványokat 49 esetben utasította el.

A bírói döntések felülvizsgálatakor, azok megsemmisítése esetén és normakontrollhatáskörökben eljárva jellemzően a következő alapjogok védelme érdekében állapította meg az Alkotmánybíróság az alaptörvény-ellenességet: magán- és családi élet védelme [Alaptörvény VI. cikk (1) bekezdés], tisztességes eljáráshoz való jog [Alaptörvény XXVIII. cikk (1) bekezdés], jogorvoslathoz való jog [Alaptörvény XXVIII. cikk (7) bekezdés], pihenéshez való jog [Alaptörvény XVII. cikk (4) bekezdés] és egészséges környezethez való jog [Alaptörvény XXI. cikk (1) bekezdés]. Az Alkotmánybíróság 8 döntésében állapította meg a jogállamiság részét képező jogbiztonság [Alaptörvény B) cikk (1)] sérelmét.

Az alapjogok védelme és a magyar alkotmányjog dogmatikájának szempontjából, időrendi sorrendben, a következő döntések részletes ismertetése szükséges a 2020. év első félévének határozatai közül.

B)

\section{3/2020. (I. 3.) AB határozat - az e-cigaretták kiskereskedelmi korlátozásainak vizsgálata}

Az Alkotmánybíróság e határozatában megállapította, hogy az Országgyülés az Alaptörvény által garantált tulajdonjog-sérelme miatt mulasztásban megnyilvánuló alaptörvény-ellenességet idézett elő azáltal, hogy az elektronikus cigaretta és a kapcsolódó termékek kiskereskedelmének koncesszióköteles dohányboltokra történő korlátozásával egyidejűleg nem rendelkezett a vállalkozáshoz való jog korlátozásával érintettek megfelelő kompenzációjáról.

A döntés alapjául országgyủlési képviselők utólagos normakontroll-indítványa és egy elektronikus cigaretta és annak kiegészítőivel kereskedő gazdasági társaság alkotmányjogi panasza szolgált, akik támadták a fiatalkorúak dohányzásának visszaszorításáról és a dohánytermékek kiskereskedelméről szóló törvény azon módosított rendelkezését, amely szerint bizonyos termékek, így az elektronikus cigaretta, utántöltő flakon és dohányzást imitáló elektronikus eszközök kiskereskedelme csak dohányboltban történhet. Az indítványozó gazdasági társaság 2011 óta kifejezetten erre szakosodva elektronikus cigaretta és annak kiegészítő termékei kiskereskedelmi értékesítésével foglalkozott az általa üzemeltetett webshopon és üzletein keresztül, 
azonban a 2016. évi jogszabály-módosítással az érintett termékekkel kapcsolatos kereskedelmi tevékenységét meg kellett szüntetnie és üzleteit be kellett zárnia, munkavállalói kétharmadát el kellett bocsátania, megmaradt árukészlete értékesíthetetlenné vált.

$\mathrm{Az}$ online értékesítés tilalma ellehetetlenítette az indítványozó gazdasági tevékenységét, a jogalkotó pedig nem rendelkezett a kártalanításáról, nem biztosított új koncessziók kiírásával lehetőséget számára, hogy tevékenységét folytathassa.

Az indítványozók szerint a módosítás diszkriminatív és sérti az egészséghez való jogot, illetve az indítványozó gazdasági társaság tulajdonhoz való jogát és a vállalkozáshoz való jogát sérti, valamint a diszkrimináció tilalmába is ütközik.

2013-tól a fiatalkorúak dohányzásának visszaszorítását célzó törvénnyel a jogalkotó a dohánytermékek kiskereskedelmét kizárólagosan az állam hatáskörébe utalt tevékenységnek minősítette - állami monopóliummá tette -, és kimondta, hogy e tevékenység gyakorlását az állam koncessziós szerződéssel meghatározott időre átengedheti. Ez utóbbi esetben a dohánytermék kiskereskedelme kizárólag a koncessziós szerződés rendelkezései által biztosított jogosultság (dohánytermék-kiskereskedelmi jogosultság) alapján és dohánytermék-kiskereskedelmi engedély birtokában végezhető. A pályáztatás lezajlott, a koncessziós szerződéseket aláírták, és a teljesen új alapokra helyezett kiskereskedelmi rendszer müködésbe lépett. A koncesszió átengedésének időtartama 20 év, így 2033-ig csak kivételes esetben nyílik mód dohánytermék-kiskereskedelmi jogosultság megszerzésére.

E szabályozási környezetbe és feltételrendszerbe lépett be három évvel később, 2016-tól az indítványozó által sérelmezett, az elektronikus cigaretta és a kapcsolódó termékek (például utántöltő flakonok és dohányzást imitáló elektronikus eszközök) kiskereskedelmére vonatkozó korlátozás. Ekkortól a dohánytermékekre vonatkozó rezsim vonatkozik rájuk is. A törvény kivételt nem tesz, az elektronikus cigaretta kiskereskedelme kizárólag dohányboltban folytatható. Ezzel egyidejüleg az elektronikus cigaretta és az utántöltő flakon távértékesítését is betiltották.

Az Alkotmánybíróság megállapította, hogy az elektronikus cigaretta kiskereskedelmi tevékenység is vállalkozási tevékenység folytatásának minősül, és mint ilyen, kiterjed rá az Alaptörvény XII. cikk (1) bekezdésében foglalt vállalkozáshoz való alapjog védelmi köre.

Az Alkotmánybíróság a határozatában a vállalkozáshoz való joggal kapcsolatban kiemelte, hogy ezen alapjog védelmi köre egyaránt kiterjed a piacra lépésre, továbbá a már megkezdett tevékenység folytatására is, hangsúlyozva azonban, hogy a szóban forgó alapjog a jogi környezet változatlanságát nem garantálja.

A támadott törvényi rendelkezések az elektronikus cigaretta használatának a viszszaszorítását és ezen keresztül az egészség - közvetlenül egy alapjog - védelmét szolgálják. Ezért az alapjogi korlátozás szükségessége igazolt. Az arányosság körében az Alkotmánybíróság vizsgálta, hogy az elérni kívánt cél fontossága és az ennek érdekében okozott alapjogsérelem súlya megfelelő arányban állnak-e egymással. A törvényhozó a korlátozás során köteles az adott cél elérésére alkalmas legenyhébb 
eszközt alkalmazni, azaz a korlátozás nem haladhatja-e meg azt a szintet, mint amit az alkotmányosan igazolható cél elérése feltétlenül megkíván.

A koncessziós rendszernek az elektronikus cigarettákra és kapcsolódó termékekre való bevezetésének - pontosabban jelen esetben: kiterjesztésének - a ténye önmagában nem alaptörvény-ellenes. A vállalkozáshoz való jog nem korlátozhatatlan alapjog, nem lehet elvitatni a jogalkotótól annak a lehetőségét, hogy más alapvető jog védelme érdekében ennek a korlátozásáról döntsön. A vállalkozáshoz való jog korlátozása szempontjából kifejezetten az a mód aggályos, ahogyan az a gyakorlatban megvalósult: a jogszabályváltozással érintett, annak hatálybalépésekor már működő, elektronikuscigaretta-kiskereskedelemmel foglalkozó vállalkozások azáltal kerültek hátrányosabb helyzetbe, hogy a jogalkotó semmilyen módon nem volt tekintettel a vállalkozási tevékenységük fenntartásához füződő alapjogukra, valamint arra az adott esetben konkrétan keletkezett kárra, amely a vizsgált jogszabály révén állt elő.

Egyrészt a jogszabályváltozás nem tartalmazott új koncessziós pályázatok kiírására vonatkozó kötelezettséget, amely potenciálisan lehetőséget adott volna a tevékenység folytatására. Másrészt pedig a tevékenység kötelező befejezésének - az azzal közvetlenül és igazolhatóan összefüggő, másképp nem érvényesíthető és egyéb úton nem ellentételezhető vagyoni hátrányok kiegyenlítését biztosító - kompenzációjáról sem rendelkezett a jogalkotó. A jogszabály módosítása tehát alapvetően a hiányosságánál fogva idéz elő aránytalan alapjog-korlátozást, és válik alaptörvény-ellenessé.

Mindezek alapján az alaptörvény-ellenes helyzet megszüntetése érdekében - figyelemmel a hatályos jog kíméletével való eljárás indokoltságára is - az Alkotmánybíróság mulasztással előidézett alaptörvény-ellenességet állapított meg, a jogalkotói mulasztás megállapításával és a jogalkotónak címzett felhívással - amely alapján a fent kifejtettek figyelembevételével a törvényalkotónak kell megtalálnia a kompenzáció megfelelő módját - ugyanis megteremthető az összhang a törvény és az Alaptörvény XII. cikkének rendelkezései között.

Az Alkotmánybíróság ugyanakkor megvizsgálta a távértékesítés generális tilalmának alkotmányosságát is. E tilalom mindenfajta - határokon átnyúló és belföldi - távértékesítésre kiterjed. Az a tény, hogy a megrendelés és házhozszállítás helyett a termék beszerzéséhez személyesen fel kell keresni az értékesítéssel foglalkozó boltot, bizonyosan korlátozza a termék elérhetőségét, így csökkenti annak a forgalmát. A támadott előírás ezért (különös tekintettel arra, hogy a jogalkotó egyidejủleg kötelező jelleggel a dohányboltokba terelte a kiskereskedelmet) alkalmas arra, hogy visszaszorítsa a termék használatát, illetve annak elterjedését.

A korlátozás szükségességét az Alkotmánybíróság megítélése szerint ugyanazok az érvek indokolják, amelyeket a kiskereskedelem dohányboltokra történő korlátozásával kapcsolatban alkotmányosan elfogadható indokként azonosítottak. Az egészségnek és különösen a fiatalkorúak egészségének a védelme a megelőzés és az elővigyázatosság elvének figyelembevételével alkotmányos alapot ad egy olyan termék széles körű elérhetőségének - a távértékesítés és ezen belül különösen az online 
kiskereskedelem mindenképpen e körbe tartozik - a korlátozására, amellyel összefüggésben bizonyítottan egészségügyi kockázatok állnak fenn.

A korlátozás arányosságával kapcsolatban figyelembe veendő, hogy a kiskereskedelmet a jogalkotó nem tiltotta meg teljesen, pusztán az egyik forgalmazási módot zárta ki az egészséghez való jog védelme érdekében, tehát a termék értékesítését nem tette lehetetlenné, azt csak nehezítette. Másrészt a tilalom nem a teljes termékkörre, csak a nikotintartalmú pára fogyasztását lehetővé tévő eszközökre terjed ki, amelyeknél az egészségkárosító hatás kockázata leginkább fennáll. Harmadrészt pedig kifejezetten a fiatalkorúak egészségének védelme szempontjából megjegyzendő, hogy bár léteznek életkor-ellenőrző rendszerek, amelyekkel kontrollálni lehet, hogy a terméket vásárló fogyasztó eléri-e a vásárláshoz szükséges alsó korhatárt, ezek az intézkedések adott esetben megkerülhetők, illetve manipulálhatók. A személyes vásárlás előírása hatékonyabban képes biztosítani azt, hogy fiatalkorúak biztosan ne juthassanak hozzá a termékhez.

A fentiek alapján a vállalkozáshoz való jog korlátozásának szükségessége és arányossága is megállapítható volt, ezért az Alkotmánybíróság a távértékesítési tilalom szabályozása alaptörvény-ellenességének megállapítására és megsemmisítésére irányuló indítványt elutasította.

\section{3048/2020. (III. 2.) AB határozat - becsületsértés, a véleménynyilvánitás határai}

Az Alkotmánybíróság a véleménynyilvánítás szabadságának értelmezése során megállapította, hogy a személyiséget szubjektíve sértő, de az emberi méltóság sérelmét el nem érő kifejezések a véleménynyilvánítás szabadsága körébe tartoznak, így azokat az Alaptörvény védi. A közösségi oldalon közösséget érintő kérdésekben rendszeresen véleményt nyilvánító személy közszereplőnek minősülhet, így a közszereplőkre vonatkozó fokozottabb türésre vonatkozó mérce alkalmazandó rá.

Az indítványra okot adó ügyben az indítványozó, aki az elkövetés időpontjában polgármester volt, a képviselő-testület egyik ülésén szólalt fel egy új ravatalozó tervezési folyamatával kapcsolatban. Felszólalásában az ügy sértettjének közösségi oldalán terjesztett álláspontot „vírusnak” nevezte. A felszólalás egésze arra utalt, hogy a sértett álláspontja kihatással van másokra, így befolyásolja az önkormányzati döntéshozatalt. A képviselö-testület ülését a televízió közvetítette, így a felszólalás előre meg nem határozható számú személy számára hozzáférhetővé vált. A sértett magánvádat emelt. A megállapított tényállás alapján a Veszprémi Járásbíróság az indítványozót bűnösnek mondta ki becsületsértés vétségében, és megrovásban részesítette.

Az elsőfokú bíróság szerint az indítványozó azzal a kijelentéssel, hogy „megérkezik a [sértett neve]-vírus", a becsület csorbítására alkalmas kifejezést használt, azzal pedig, hogy ezt a képviselö-testület nyilvános ülésén tette meg, tudva, hogy a helyi televízió a képviselö-testületi ülést leközli, a becsület csorbítására alkalmas kifejezést előre meg nem határozható számú személy ismerhette meg. A bíróság figyelembe 
vette, hogy a becsület csorbítására való alkalmasságot nem a sértett egyéni megítélése szerint, hanem az alapján kell megítélni, hogy objektíven alkalmas-e a becsület csorbítására. A bíróság a sértett „vírussal” való azonosítását tekintette a becsület csorbítására alkalmasnak. Megállapította azt is, hogy az indítványozó és a sértett is közszereplők, akik fokozottabban kötelesek türni a kritikai véleményeket. Ugyanakkor úgy ítélte meg, hogy a kifejezés öncélú volt, a vitát nem vitte előre, kizárólagos célja a sértett megalázása volt. Ezért az indítványozót becsületsértés vétségében marasztalta. Fellebbezést követően a Veszprémi Törvényszék a bíróság ítéletét helybenhagyta.

A Törvényszék végzésével szemben az indítványozó alkotmányjogi panasszal fordult az Alkotmánybírósághoz, a döntés ugyanis szerinte sérti az Alaptörvény IX. cikk (1)-(2) bekezdésben rögzített véleménynyilvánításhoz való jogát, indítványozta tehát a bírói döntés megsemmisítését. Előadta, hogy a közéleti kommunikációnak magasabb szintű védelmet kell élveznie, amelybe bizonyos fokig a túlzások, provokációk is beletartozhatnak. Ha a közlés a közéleti vitához hozzájárul, akkor a közélet szereplőinek fokozott tűrési kötelezettségük van, és a szólásszabadságot kell előnyben részesíteni. Vitatta az indítványozó, hogy közlése öncélú lett volna, ami a társadalmi vitát nem viszi előre.

Az Alkotmánybíróság megállapította, hogy az ügy az Alaptörvény IX. cikkében biztosított véleménynyilvánítás jogával összefüggésben vetette fel azt az alapvető alkotmányjogi kérdést, hogy hol húzódik a véleménynyilvánítás szabadságának és a személyiség védelmének a határvonala.

Az Alaptörvény IX. cikk (1) bekezdése értelmében „[m]indenkinek joga van a véleménynyilvánítás szabadságához". A véleménynyilvánítás szabadsága kommunikációs jog. Demokratikus társadalom csak abban az esetben jöhet létre és maradhat fenn, ha lehetőség van arra, hogy a különböző (gyakran egymással ellentétes) vélemények a társadalmat formálhassák. A szólásszabadság különleges védelmet követel akkor, amikor közügyeket és a közhatalom gyakorlását, a közfeladatot ellátó, illetve a közéletben szerepet vállaló személyek tevékenységét érinti. A társadalmi, politikai viták jelentős részben éppen abból állnak, hogy a közélet szereplői, illetve a közvitában részt vevők egymás elképzeléseit, politikai teljesítményét és azzal összefüggésben egymás személyiségét is bírálják. A sajtónak pedig alkotmányos küldetése, hogy a közhatalom gyakorlóit ellenőrizze, aminek részét képezi a közügyek alakításában részt vevő személyek tevékenységének bemutatása és - akár rendkívül éles hangú - kritikája.

Az Alkotmánybíróság a korábbi alkotmánybírósági gyakorlatra támaszkodva alakította ki azt a tesztet, amelynek első lépéseként azt kell vizsgálni, hogy az adott közlés közügyekben, közérdekü vitákban való álláspontot tükröz-e, vagyis a közügyek szabad vitatásával áll-e összefüggésben. Második lépésként a bíróságoknak azt kell eldöntenie, hogy a közlés tényállításnak vagy értékítéletnek minősül-e: a közügyeket érintő értékítéletek szabad folyása biztosított, hiszen a tényállításokkal szemben az értékítéletek közös sajátossága, hogy igazságtartalmuk nem ellenőrizhető és nem igazolható. Végül vizsgálni kell, hogy a korlátozás nem lépte-e túl a véleménynyilvánítás határát. A véleményszabadság már nem nyújt védelmet az olyan öncélú, a közügyek vitatásának 
körén kívül eső, így a magán- vagy családi élettel kapcsolatos közlésekkel szemben, amelyek célja puszta megalázás, illetve a bántó vagy sértő kifejezések használata vagy jogsérelem okozása. A személyiségvédelem és a véleménynyilvánítás szabadságának ütközése során végül nem hagyható figyelmen kívül az sem, hogy a használt, az érintett becsületét sértő kifejezés önálló információs értékkel bír-e. Ha ugyanis ilyen információs érték nem állapítható meg, a kifejezés a közéleti vitát nem mozdítja előre, akkor a kifejezés nem élvezi az Alaptörvény IX. cikkének védelmét.

A bíróság által megállapított tényállás szerint az indítványozó polgármesterként az önkormányzat képviselő-testületi ülésén a sértett tevékenységét „vírusnak” nevezte. Elsőként azt kellett az Alkotmánybíróságnak vizsgálnia, hogy ez a közlés a védett véleménynyilvánítás szabadságába tartozik-e, illetve közéleti közlésnek minősül-e. Az indítványozó ezt a kifejezést az önkormányzat hatáskörébe tartozó, fejlesztéseire vonatkozó terveivel kapcsolatba hozható témában mondta: az indítványozó és a sértett között egy beruházás szükségessége tekintetében volt vita. E kérdés egyértelműen közéleti, így a megnyilvánulás a szólásszabadság fokozottabb védelmét élvezi. A védelmet erősíti az is, hogy a véleménynyilvánítás helyszíne a képviselö-testületi ülés volt, amely a társadalmi viták elsődleges, kifejezetten e célra rendelt helyszíne.

Bár maga a sértett az őt sértő megnyilvánuláskor nem volt a település képviselője, az általa indított közösségi oldalon rendszeresen véleményt nyilvánított a közösséget érintő kérdésekben, így közszereplőnek minősült. A kommunikáció során tehát egy közszereplő egy másik közszereplőre vonatkozóan tett kijelentést, közéleti kérdésben, a közéleti viták lefolytatásának tipikus helyszínén. Ezért az Alkotmánybíróság szerint a véleménynyilvánításra az Alaptörvény IX. cikkének különösen kiemelt védelme vonatkozik.

Jelen ügyben egyértelmủ az is, hogy az indítványozó nem tényállítást, hanem értékítéletet fogalmazott meg; logikusan fel sem merülhet, hogy a sértett a szó biológiai értelmében vírus lenne. A teszt alapján végül az Alkotmánybíróság azt vizsgálta, hogy a használt kifejezés „öncélú gyalázkodás” volt-e, vagy a közéleti vitát előremozdító megállapítás, azaz volt-e önálló információs tartalma annak, hogy a sértett tevékenységét a víruséhoz hasonlította. E vonatkozásban az Alkotmánybíróság kiemelte, hogy az információs tartalom meghatározásánál figyelembe kell venni a közlés célját, azaz azt, hogy mi volt az az üzenet, amit a véleménynyilvánító meg kívánt osztani. A tényállás szerint az indítványozó a „vírus” kifejezéssel arra utalt, hogy a sértett befolyásolta más személyek, köztük képviselők magatartását, akik így véleményüket a sértettéhez igazították. A szóban forgó kifejezés nem pusztán személyt sértő gyalázkodás, hanem a sértett magatartásának közösségi hatására vonatkozó utalás. Erre tekintettel nem állapítható meg a közlés öncélú jellege.

Az Alaptörvény IX. cikk (4) bekezdése szerint a véleménynyilvánítás szabadságának a gyakorlása nem irányulhat mások emberi méltóságának a megsértésére. Ez a rendelkezés a véleménynyilvánítás szabadságának határát jelöli ki. A személyiséget szubjektíve sértő, de az emberi méltóság sérelmét el nem érő kifejezéseket az Alaptörvény IX. cikke védi. 
A fentieket összegezve az Alkotmánybíróság úgy döntött, hogy az indítványozó értékítéletet tartalmazó közlését az Alaptörvény IX. cikke különösen kiemelt védelemben részesíti, amely korlátozásának legitim célja ugyan a személyiségvédelem, de jelen esetben, mivel a közlés nem volt öncélú gyalázkodás, a véleménynyilvánítás szabadságának a korlátozása aránytalan volt. Az általános hatáskörü bíróság az alapjogi összeütközést helyesen tárta fel, ám azt nem az Alaptörvény IX. cikkéből következő szempontok alapján mérlegelte, így a támadott döntés sértette az indítványozó véleménynyilvánítási szabadságát, erre tekintettel az Alkotmánybíróság a bírói döntést megsemmisítette.

\section{3049/2020. (III. 2.) AB határozat - csendháboritás, vallásgyakorlás}

Az Alkotmánybíróság e határozatában megállapította, hogy a vallási meggyőződés kinyilvánításának részeként a vallási szertartás hangos végzése is a vallásszabadság alapjogvédelmi körébe tartozik. A szertartás többszöri, hangos végzésének korlátozását a szomszédok pihenése, otthonuk nyugalmának biztosítása azonban igazolhatja.

Az indítványozó alkotmányjogi panasszal támadta a Miskolci Járásbíróság végzését. Az alapügy tényállása szerint, mivel az indítványozó túl hangos vallásos cselekményével zavarta mások pihenését, csendháborítás szabálysértésének elkövetése miatt a szabálysértési hatóság az indítványozót 50000 forint pénzbírsággal sújtotta. Az indítványozó kifogásában előadta, hogy az eljárásban meghozott, bírságot kiszabó határozat a szabad vallásgyakorláshoz füződő jogát sérti.

A szabálysértési eljárást követő bírósági eljárás végén a járásbíróság a határozatot hatályában tartotta. A bíróság kifejtette, hogy a szabálysértési hatóság mind a tényállást, mind az eljárás alá vont személy által elkövetett cselekmény minősítését és szabálysértési felelősségét helyesen állapította meg. A bíróság azt is kiemelte, hogy az adott ügyben a szabad vallásgyakorláshoz való alapjog és a testi és lelki egészséghez való alapjogon belül a pihenéshez való jogütközött egymással. Utalt továbbá arra, hogy az alapjogok az alapvető jog lényeges tartalmának tiszteletben tartásával a feltétlenül szükséges mértékben, az elérni kívánt céllal arányosan korlátozhatók.

A bíróság hangsúlyozta, hogy az eljárás alá vont személynek joga van a szabad vallásgyakorláshoz, azonban az nem járhat mások alapvető jogainak megsértésével. Megállapította továbbá, hogy nem arról van szó, hogy az eljárás alá vont személyt bárki akadályozná vallásos cselekmények, például az imádkozás, az éneklés megvalósításában, hanem arról, hogy tevékenységét olyan hangerővel végezze, hogy az másokat ne zavarjon. Az eljárásban bizonyítékként felhasználták a feljelentő által rögzített hangfelvételt, valamint a tanúk által elmondottakat.

Ezt követően az indítványozó alkotmányjogi panaszt nyújtott be az Alkotmánybírósághoz. Az indítvány szerint a kifogásolt bírói döntés folytán sérült az indítványozónak a vallásszabadsághoz való joga, valamint a hátrányos megkülönböztetés tilalma. Az indítványozó szerint alapvető alkotmányjogi jelentőségű kérdés, hogy 
az alapjogok összeütközése esetén korlátozható-e a lelkiismereti és vallásszabadság joga.

Az Alkotmánybíróság megállapította, hogy az ügy az Alaptörvény VII. cikk (1) bekezdésében biztosított szabad vallásgyakorláshoz füződő joggal összefüggésben alapvető alkotmányjogi jelentőségủ kérdést vetett fel abban a tekintetben, hogy a bírói döntés folytán sérült-e az indítványozó szabad vallásgyakorlásához való joga. Az Alkotmánybíróság alkotmányossági vizsgálata során arra kereste a választ, hogy sérti-e az indítványozó szabad vallásgyakorlásához füződő jogát, hogy az indítványozó túl hangos imádkozását indokolatlan zajokozásként értékelve csendháborítás szabálysértésének elkövetése miatt az indítványozót szabálysértési bírság megfizetésére kötelezték.

Az Alaptörvény VII. cikk (1) bekezdése alapjogként rögzíti a gondolat, a lelkiismeret és a vallás szabadságához való jogot, továbbá meghatározza annak tartalmi összetevőit. A vallásszabadsághoz való jog négy eleme: a vallási meggyőződés szabad megválasztásának, kinyilvánításának, gyakorlásának és a tanításának szabadsága. Az Alkotmánybíróság már korábban kifejtette, hogy az állam az egyéni jogokkal összefüggésben egyrészt negatív magatartásra, tartózkodásra kötelezett, nevezetesen, hogy ne korlátozza az egyén alapvető jogait. Ugyanakkor az állam kötelessége az alapvető jogok „tiszteletben tartása” mellett nem merül ki abban, hogy tartózkodik az egyéni jogok megsértésétől, hanem emellett gondoskodnia kell a vallásszabadság érvényesüléséhez szükséges feltételekről is, azaz az egyéni igényektől függetlenül a vallásszabadsággal kapcsolatos értékek és élethelyzetek védelméről. A vallásgyakorlás szabadsága, a hagyományos kultuszszabadság mellett azt az általános szabadságjogot jelenti, amelynek lényege a meggyőződésből fakadó cselekvés fokozott védelme.

Az Alkotmánybíróság megvizsgálta, hogy a bírói döntés korlátozta-e az indítványozó szabad vallásgyakorlását. A vallásszabadság négy fogalmi eleme közül jelen ügy a vallási meggyőződés szabad kinyilvánításához, illetve gyakorlásához füződő jogát érintette. A vallási meggyőződés vallási cselekményekkel, szertartásokkal kifejezésének szabadsága a vallásszabadság fokozottan védett tartalmát képezi. Ugyanakkor a vallási meggyőződés kinyilvánítása és a vallásgyakorlás a kultuszszabadság védelmi körén túl eső magatartásokat és tevékenységeket is magában foglal.

$\mathrm{Az}$ Alaptörvény elsődleges kötelezettségként állapítja meg az állam tevőleges védelmi kötelezettségét az ember alapjogainak védelmére nézve. Ugyanakkor az Alkotmánybíróság vonatkozó határozataiban arra nézve, amikor az alapjogi konfliktus a jogalanyok egymás közötti jogviszonyában akként merül fel, hogy az egyik magánszemély alapjogát a másik személy alapjoga veszélyezteti (konkuráló/versengő alapjogok), az állam tevőleges védelmi kötelezettségére nézve annak közvetítő, kiegyenlítő szerepét hangsúlyozta. Az Alaptörvény szerint alapvető jog más alapvető jog érvényesülése vagy valamely alkotmányos érték védelme érdekében, a feltétlenül szükséges mértékben, az elérni kívánt céllal arányosan, az alapvető jog lényeges tartalmának tiszteletben tartásával korlátozható. Az alapjog-korlátozásnak e tesztje mindenekelőtt a jogalkotót kötelezi, hatáskörükhöz igazodva azonban a jogalkalmazókat is köti. A bíróságoknak a jogszabály engedte értelmezési mozgástér keretein belül 
az érintett alapjog korlátozását kizárólag a szükséges és arányos mértékű beavatkozás szintjére kell szorítaniuk.

Az indítványozó a jogerős bírói döntés folytán (amely hatályában fenntartotta az elsőfokú szabálysértési hatóság csendháborítás szabálysértésének elkövetése miatti bírságot kiszabó határozatát, az indítványozó túl hangos imádkozását indokolatlan zajokozásként értékelve) az Alaptörvény VII. cikk (1) bekezdésbe foglalt szabad vallásgyakorláshoz való jogának sérelmét állította.

A járásbíróság utalt arra, hogy az Alaptörvény VII. cikk (1) bekezdésében rögzített vallásszabadsághoz való jog szükségesség-arányosság elve alapján korlátozható. Megállapította továbbá, hogy az eljárás alá vont személy szabad vallásgyakorláshoz való joga ütközött más emberek pihenéshez való jogával. Emellett azonban azt is kifejtette, hogy „[n]em arról van szó, tehát, hogy az eljárás alá vont személyt bárki akadályozná a vallásos cselekmények, például imádkozás, éneklés megvalósításában, hanem arról, hogy ezt a tevékenységét úgy, olyan hangerővel kell végeznie, hogy azzal másokat ne zavarjon".

A vallási meggyőződés kinyilvánításának részeként a szabad vallásgyakorlás jogának védelmét élvezi (az alapjog részeként) az egyén vallásgyakorlása, így a konkrét ügyben az indítványozó által végzett vallási szertartás (például ima, éneklés) is. Az alapjogvédelem körébe esik ennek alapján a vallási jellegű tevékenység elvégzése, gyakorlásának a lehetősége, illetve az, hogy az egyént ebbéli tevékenységének végzése során ne akadályozzák. Ugyanakkor maga a szabad vallásgyakorlás joga mint alapjog, az Alaptörvény szerint, amennyiben azt legitim ok szükségessé teszi, arányos mértékben korlátozható. Mindezekre tekintettel az Alkotmánybíróság azt vizsgálta, hogy milyen alapjogi védelem illeti meg az olyan vallási szertartás végzését, amely más harmadik személyeket - a szertartás hangereje miatt - zavar. Azaz a bírói döntés, azzal, hogy mások zavarására alkalmasnak állapította meg az indítványozó imádkozásának a hangerejét - tehát nem a tevékenységet, hanem annak hangerejét - és ezért szabálysértési bírságot állapított meg, korlátozta-e a vallási meggyőződés szabad kifejezésének és gyakorlásának alapjogát.

Az Alkotmánybíróság elvi éllel állapította meg, hogy a vallási szertartás hangos végzése is - a vallási meggyőződés kinyilvánításának részeként - a vallásszabadság alapjogvédelmi köre alatt áll. Ennek alapján a konkrét ügyben helyesen állapította meg a bíróság, hogy a korlátozást igazolhatja a szomszédok pihenése, otthonuk nyugalmának biztosítása. Ezt követően ugyanakkor az is vizsgálandó, hogy ennek a tevékenységnek a hangos gyakorlása a körülmények (a tevékenység végzésének helye, amely konkrét ügyben egy társasház, az időpontja és annak időtartama, továbbá a tevékenység végzésének rendszeressége, a zavarás mértéke és módja, a társadalmi szokások stb.) miatt arányos mértékű-e.

Az Alkotmánybíróság vizsgálata alapján nem állapítható meg, hogy az indítvánnyal támadott bírói döntés helytelenül értékelte volna a versengő érdekek ütközését. Nem ellentétes az Alaptörvény VII. cikkével az az érvelés, amely szerint a vallásos meggyőződést ki lehet fejezni imával, illetve énekléssel, azonban annak túlzott hangereje 
adott esetben már mások (a szomszédok) otthoni nyugalma, pihenése (egyúttal magánszférája) aránytalan zavarásának minősül. Azaz a konkrét ügyben az indítványozó vallási meggyőződésének ilyen módon történő kifejezését már legitim módon korlátozza a társasházi szomszédok nyugalma, pihenése, amennyiben annak túlzott hangerővel történő végzése rendszeresen történik. Az Alkotmánybíróság megerősítette, hogy a vallási meggyőződés kinyilvánítása részeként az imádkozás módjának megválasztását legitim módon korlátozhatja mások nyugalma, pihenése, ez azonban mindig egyéni mérlegelést tesz szükségessé.

Az Alkotmánybíróság nem hivatott állást foglalni valamely vallás hittételeivel öszszefüggésben, így abban sem, hogy az imádkozás hangereje mennyiben kapcsolódik a meggyőződés központi eleméhez. Elismeri, hogy egyes esetekben maga a hangerő mértéke is a szakrális szertartás része lehet, ilyenkor eltérő eredményre vezethet, hogy a bíróság döntésével korlátozta-e az indítványozó vallásgyakorláshoz való jogát, továbbá amennyiben igen, abban az esetben az szükséges és arányos volt-e. (Ilyen eset lehet, amikor a szertartás csak nagyobb zajjal, hangerővel végezhető, például körmenet, vallási célból történő harangozás.) Ezekben az esetekben a vallási szertartás velejárója, része a nagyobb hangerő, ezért azok rövidsége is ellensúlyozhatja a kívülállók zavarását. Az Alkotmánybíróságnak és a bíróságoknak ilyen ügyekben vizsgálatuk során a magyar kulturális és civilizációs szokásokat is figyelembe kell venniük.

Az Alkotmánybíróság a fentiek alapján a konkrét alkotmányossági vizsgálat során arra a következtetésre jutott, hogy az alkotmányjogi panasszal támadott bírói döntés nem jelentette az indítványozó vallásszabadságának alaptörvény-ellenes korlátozását, továbbá nem korlátozza és nem akadályozza az indítványozót a jövőre nézve a csendesebb, de a vallási előírásoknak megfelelő imádkozásban. Ezért az indítványt elutasította.

\section{3068/2020. (III. 9.) AB határozat - gyermek jogellenes elvitele}

Az Alkotmánybíróság e határozatában a gyermek jogellenes visszavitele tárgyában folyó eljárásokban a tisztességes eljáráshoz való jog védelmében olvasztott ki korábbi gyakorlatához képest a bizonyításra vonatkozó további garanciákat.

Az alkotmánybírósági ügy előzménye az volt, hogy egy magyar anyával szemben egy olasz apa gyermek jogellenes visszatartása miatt bírósági eljárást indított, azért, mert az egyébként részben Spanyolországban, részben pedig Magyarországon élő szülők (házastársak) közül az anya akként döntött, hogy a négyéves fiú, illetve a kétéves leánygyermekével - a szülők házasságának megromlása miatt - a továbbiakban nem külföldön, hanem Magyarországon kíván élni. A bíróságok a bizonyítékokat akként értékelték, hogy a gyermekek szokásos tartózkodási helye Spanyolországban volt, az apa és az anya együttesen gyakorolták a szülői felügyeleti jogokat, az anya pedig a gyermekeket jogellenesen vitte el Spanyolországból (nem engedte vissza Ibizára).

Az Alkotmánybíróság egy korábbi határozatában [3375/2018. (XII. 5.) AB határozat, Abh.] megállapította, hogy a korábbi eljárásban a Kúriai, valamint az ügyben 
hozott alacsonyabb fokú végzések is alaptörvény-ellenesek voltak, ezért azokat megsemmisítette. Az ezt követően megismételt eljárásban hozott végzéseket támadták alkotmányjogi panasszal.

Az indítványozó a tisztességes bírósági eljáráshoz való jog sérelmét jelen ügyben abban látta, hogy a bíróságok a megismételt eljárásban eljárásjogi hibákat ejtettek. Noha a bíróság kirendelte az igazságügyi szakértőt, az indítványozó által feltett kérdésekből egynek sem adott helyt, mint ahogyan annak az indítványának sem, hogy a bíróság vonjon be társszakértőt, illetve a felekre is kiterjedő szakértői vizsgálatot rendeljen el. Az indítványozó szerint az első fokon eljáró bíróság - az Alkotmánybíróság korábbi határozatával ellentétben - a felajánlott bizonyítási indítványoknak nem adott helyt, megfosztva ezzel az indítványozót a bizonyítás lehetőségétől. Utalt arra is, hogy a bíróságok nem vizsgálták kellő alapossággal és körültekintéssel azt, hogy a gyermek Spanyolországba való visszavitele a gyermek számára milyen pszichés vagy testi következményekkel járna. Mindezen érvek miatt az indítványozó szerint a bírósági végzések sértik a tisztességes bírósági eljáráshoz való jogot, ezért alaptörvény-ellenesek.

Az Alaptörvényben biztosított jog sérelmének lényege a konkrét ügyben az volt, hogy a tisztességes bírósági eljáráshoz való alapjogot sérti-e az, ha a bizonyítási eljárásban a bíróság a szakértő kirendelése során az egyik fél, jelen esetben éppen a bizonyításra kötelezett fél által a szakértő részére feltenni indítványozott kérdések egyikét sem teszi fel, megfosztva ezzel az egyik felet a bizonyítás egyik eszközétől, ellehetetlenítve ezzel az egyik fél egyik bizonyítási eszközének érvényesülését. Az Alkotmánybíróság azt vizsgálta, hogy sérti-e a tisztességes bírósági eljáráshoz való jogot az a körülmény, hogy a bíróság a bizonyítási eljárást (vagy a bizonyítás egyik eszközét) egyoldalúan alkalmazza, és emiatt annak eredményét is egyoldalúan veszi figyelembe, akképp, hogy ezzel a kiskorú gyermekek érdekei a határozat meghozatala során figyelmen kívül maradtak.

A támadott bírói döntések az indítványozó szerint olyan eljáráson alapulnak, amelyek a bizonyíték(ok) igénybevételének lehetőségét nagymértékben észszerütlenül korlátozták, illetve az indítványozó szerint lényegében a bizonyítást ellehetetlenítették. A tisztességes bírósági eljáráshoz való jog sérelmének vizsgálata a többi alapjoghoz képest ebben a tekintetben részben speciális. Ahhoz ugyanis, hogy az Alkotmánybíróság meg tudja állapítani ennek az alapjognak az esetleges sérelmét, a bírósági eljárást érdemben kell megvizsgálnia. Ugyanakkor az Alkotmánybíróság jelen ügyben nem negyedfokú bíróságként járt el, és nem mérlegelte újra a bizonyítékokat (a bizonyítást), hanem azt vizsgálta meg, hogy az indítványozónak objektíve lehetősége volt-e a bizonyításra, illetve a bizonyítékok előterjesztésére.

A tisztességes eljáráshoz való jog több garanciális szabályból áll. Az Alaptörvény XXVIII. cikk (1) bekezdésében foglalt tisztességes eljáráshoz való jog részjogosítványai különösen: a bírósághoz fordulás joga, a tárgyalás igazságossága, a tárgyalás nyilvánosságának és a bírói döntés nyilvános kihirdetésének a követelménye, a törvény által létrehozott bíróság, a bírói függetlenség és a pártatlanság kívánalma, továbbá az észszerű határidőn belüli elbírálás követelménye. 
Az Alkotmánybíróság eddigi gyakorlatában a tisztességes bírósági eljáráshoz való jog érvényesülésének megítélését minden esetben tartalmi vizsgálathoz kötötte: mint ahogyan jelen ügyben is, elemezte az alapjog állított sérelmére vezető jogszabályi környezetet és bírói döntést, a szabályozás célját és a konkrét ügy tényállását, majd pedig - mérlegelés eredményeként - mindezekből vont le következtetéseket az adott esetre nézve megállapítható alapjogsérelemre nézve. Az Alkotmánybíróság vizsgálta, hogy a rendes bírósági eljárásban - amiatt, hogy a bíróságok nem tettek eleget az Alkotmánybíróság korábbi határozatában foglaltaknak - sérült-e az indítványozó tisztességes bírósági eljáráshoz való joga.

Az Alkotmánybíróságnak azt kellett megvizsgálnia, hogy az eljáró bíróságok az Alkotmánybíróság jelen ügy előzményéül szolgáló ügyben született határozatában foglaltaknak eleget tettek-e. Az Alaptörvény XXVIII. cikk (1) bekezdésében foglalt tisztességes eljárás követelményéből a bíróságoknak az a kötelezettsége fakad, hogy a gyermek érdekeit a lehetö legszélesebb körben tárják fel, és ehhez a gyermek jogellenes elvitele ügyében folytatott eljárásban az összes lehetséges, a felek által felajánlott bizonyítási eszközt igénybe vegyék annak érdekében, hogy a kiskorú gyermek kiemelten védett érdekeit nyilvánvalóan és egyértelmüen megállapíthatóvá tegyék.

Emiatt az Alkotmánybíróság jelen ügyben azt állapította meg, hogy a bíróságok a szakértő-kirendelési kötelezettségüknek csak formálisan tettek eleget, tartalmilag azonban nem.

A bíróságok által vizsgált esetben a gyermekek kifejezetten alacsony életkorúnak minősültek, ezért fokozottan ki voltak téve annak, hogy az apjukhoz (Spanyolországba) történő visszavitelük esetén testi vagy lelki károsodást szenvednének vagy a visszavitel más módon elviselhetetlen helyzetet teremtene számukra. Emiatt az ilyen ügyekben a bíróságnak fokozott körültekintéssel kell eljárnia, és a gyermek(ek) érdekeit a lehető legtöbb rendelkezésre álló bizonyítási eszközzel kell felderíteni és védeni. Különösen hangsúlyosak a gyermekek érdekei amiatt is, mert a nemzetközi megállapodások mellett az Alaptörvény XVI. cikk (1) bekezdése külön is rendelkezik arról, hogy minden gyermeknek joga van a megfelelő testi, szellemi és erkölcsi fejlődéshez szükséges védelemhez és gondoskodáshoz. Erre tekintettel a gyermekek érdekeit közvetlenül érintő eljárásokban különös hangsúlyt kell kapnia az eljárás tisztességes voltának.

A bíróságok jelen ügyben egyfelől részletesen megvizsgálták azokat az objektív körülményeket (szokásos tartózkodási hely, elvitel jogellenessége, szülői felügyelet tényleges gyakorlása), amelyeket a nemzetközi és a hazai szabályozás is megkíván. Ugyanakkor a bíróságok ebben a megismételt eljárásban sem vizsgálták kellő alapossággal és körültekintéssel azt, hogy a gyermekek visszavitele a gyermekek számára milyen pszichés vagy testi következményekkel járna, járhatna. A tisztességes eljáráshoz való jog sérelmét jelen ügyben az okozta, hogy a bíróság nem tett eleget a korábbi Abh.-ban foglalt kötelezettségének, és a szakértői véleményt arra a kérdésre szűkítette, hogy milyen a gyermekek viszonyulása a korábbi spanyolországi szokásos tartózkodási helyükhöz. 
Mindezekre tekintettel az Alkotmánybíróság azt állapította meg, hogy a vizsgált bírósági határozatok hiányosságai a tisztességes eljáráshoz való jog sérelmét eredményezték, és ezzel a gyermekek Alaptörvényben foglalt jogainak kiüresedéséhez vezettek. Az ilyen típusú eljárásokban a gyermekek érdekei feltárásának elmaradása általában sérti a tisztességes eljáráshoz való jogot.

Emiatt jelen ügyben az Alkotmánybíróság arra a megállapításra jutott, hogy a bíróságok tartalmilag nem tettek eleget bizonyítási kötelezettségüknek. A szakértő formális kirendelése nem elegendő ahhoz, hogy egy bírósági eljárásban a tisztességes eljáráshoz való jog maradéktalanul érvényesülhessen. Ehhez az is szükséges, hogy tartalmilag is lehetősége legyen a feleknek a bizonyítékok előterjesztésére, jelen ügyben a szakértőhöz kérdések intézésére. Az olyan eljárás, amely ennek nem tesz eleget, sérti a tisztességes eljáráshoz való jogot.

Az Alkotmánybíróság hangsúlyozza ugyanakkor, hogy a bíróság a bizonyítás eredményét szabadon mérlegeli, és ez alapján hozza meg döntését. Ebbe a helyzetbe azonban rendes bíróságok csak akkor kerülhetnek, ha a rendelkezésre álló és felajánlott bizonyítási eszközöket nemcsak formálisan, hanem tartalmilag is figyelembe veszik, és azok eredményét a határozatuk meghozatala során fel is használják, döntéseiket ezzel megindokolják.

\section{7/2020. (V. 13.) AB határozat - birói jogvédelem adatszolgáltatási kötelezettség elmulasztása esetén}

Az Alkotmánybíróság e határozatában megállapította, hogy az Országgyülés mulasztással előidézett alaptörvény-ellenességet valósított meg azáltal, hogy az információs önrendelkezési jogról és az információszabadságról szóló törvénybe foglalt, nem közfeladatot ellátó szerv tájékoztatási kötelezettségének nem teljesítése esetére nem biztosított hatékony bírói jogvédelmet az adatigénylőnek.

Az Alkotmánybíróság eljárása a Fővárosi Îtélőtábla bírói tanácsának kezdeményezésére indult. A bíróság az előtte folyamatban levő polgári per felfüggesztése mellett az információs önrendelkezési jogról és az információszabadságról szóló törvény (Infotv.) egyik rendelkezésével összefüggésben kezdeményezte az Alkotmánybíróság eljárását, a közérdekủ adatok nyilvánossága elvének [Alaptörvény VI. cikk (3) bekezdés] sérelme miatt.

A bírói kezdeményezésre okot adó ügyben egy gazdasági társasághoz (kérelmezett) közérdekủ adatigényléssel fordult egy magánszemély (a továbbiakban: kérelmező) egy európai uniós forrásból finanszírozott útépítési projekt részleteivel kapcsolatban. A projekt beruházója a Nemzeti Infrastruktúra Fejlesztő Zrt., a kérelmezett pedig a vele megkötött szerződés teljesítése érdekében létesített jogviszonyt további cégekkel, az építőanyagok eladóival. Ez utóbbi szerződések adataira vonatkozott az adatigénylés. A kérelmezett az adatigénylés teljesítését megtagadta, a kérelmező bírósághoz fordult. A másodfokú bíróság szerint az eljárás akadályát képezte az Infotv. 27 . \$ (3b) bekezdése, amely szerint a tájékoztatást igénylő kérelmező csak a tájékoztatásra 
kötelezett felett törvényességi felügyelet gyakorlására jogosult szerv (a cégbíróság) eljárását kezdeményezheti. Az Infotv. szerint a közérdekủ adatigény elutasítása esetében a közfeladatot ellátó szerv ellen lehet pert indítani, ám a kérelmezett nem közfeladatot ellátó szerv. Ebből következően a bíróságnak az Infotv. 27. $\$$ (3a) bekezdésére alapított igény érvényesítésére irányuló pert a polgári perrendtartásról szóló törvény alapján meg kellene szüntetnie. A bíróság ezért az Alkotmánybírósághoz fordult.

Az indítvány szerint a benyújtott adatigénylés is a közérdekű adatok megismeréséhez való jog védelmi körébe tartozik. Az alapjog lényegi tartalma a hatékony és teljes bíróság előtti jogérvényesítés lehetősége. Az adat megismertetésére való kötelezés lehetőségét, a bírósági végrehajtást, az adatkérőre vonatkozó kedvező bizonyítási szabályokat és a jogorvoslat lehetőségét a törvényességi felügyeleti eljárás azonban nem garantálja. A bírói út kizárása - az alapjog érvényesülését lehetővé tevő garanciák kikapcsolása - azt jelenti, hogy az Infotv. támadott rendelkezése korlátozza a közérdekből nyilvános adatok megismerhetőségét, az alapjogot.

Az üggyel kapcsolatban megkeresett igazságügyi miniszter bemutatta az Infotv. háromszintủ rendszerét: 1 . a közfeladatot ellátó szervek esetében alkalmazott, a közérdekủ és a közérdekből nyilvános adatok megismerhetőségét biztosító rezsim (közérdekű adatigénylés); 2. a szolgáltatást nyújtó szervek/személyek kezelésében lévő, közérdekből nyilvános adatok megismerhetősége, (az 1. pont szerinti rezsimmel azonos); és 3. a közérdekből nyilvános adattá minősített üzleti titkok megismerhetősége: közfeladatot ellátó szervek esetében az általános (az 1. és 2. pont szerinti) szabályok érvényesek, míg mások esetében az Infotv. $27 . \mathbb{\$}(3 \mathrm{~b})$ bekezdése szerinti külön megismerési rezsim alkalmazandó (úgynevezett „tájékoztatási kötelezettség”). A szabályozás célja a közpénzekkel való gazdálkodás átláthatóságának a biztosítása. A különbségtétel indoka az, hogy „közfeladatot ellátó szervek esetében [...] a jogalkotónak az Alaptörvény VI. cikk (3) bekezdéséből fakadó kötelezettsége - az állam demokratikus működésének ellenőrzése megvalósítása érdekében - magasabb szintủ mércét feltételez". Az államháztartáson kívüli szereplők esetében intézményesített tájékoztatási kötelezettség „alapvetően az információszabadság érvényesítését kisegítő szabályként érvényesül”.

Az Infotv. szerint közérdekből nyilvános adatként nem minősül üzleti titoknak a központi költségvetés, illetve az európai uniós támogatás felhasználásával kapcsolatos adat, valamint az az adat, amelynek megismerését vagy nyilvánosságra hozatalát külön törvény közérdekből elrendeli. Az a szervezet, amely az államháztartás alrendszerébe tartozó valamely személlyel pénzügyi vagy üzleti kapcsolatot létesít, köteles e jogviszonnyal összefüggő és közérdekből nyilvános adatra vonatkozóan - erre irányuló igény esetén - bárki számára tájékoztatást adni. Az Infotv. szabálya alapján, ha a tájékoztatásra kötelezett a tájékoztatást megtagadja, a tájékoztatást igénylő a tájékoztatásra kötelezett felett törvényességi felügyelet gyakorlására jogosult szerv eljárását kezdeményezheti.

Az Alkotmánybíróság úgy határozott, hogy a bírói kezdeményezés nem volt megalapozott, ezért az indítványt elutasította. Azonban vizsgálata során észlelte, hogy 
a szabályozás tartalma hiányos, és mulasztásban megnyilvánuló alaptörvény-ellenességet állapított meg.

A közérdekű adatok megismeréséhez és terjesztéséhez való jog az Alaptörvényben garantált alapjog. E jog (összefoglaló néven: az információszabadság) az Alkotmánybíróság gyakorlata szerint „az informáltsághoz való jogot, az információk megszerzésének szabadságát és állami elismerését, továbbá biztosítását jelenti”, amely az „információkhoz való hozzáférhetőség, az információk szabad áramlása különösen a közhatalom és az állam szervei tevékenységének átláthatósága körében alapvető jelentőségü”. Az Alaptörvény továbbá $A$ közpénzek című fejezetében rögzíti a nemzeti vagyonra, a közpénzekre kiterjedően az átlátható gazdálkodás követelményét. Kifejezetten rendelkezik arról is, hogy „[a] közpénzekre és a nemzeti vagyonra vonatkozó adatok közérdekű adatok", függetlenül attól, hogy ezeket ki vagy mely szervezet birtokolja. Az Infotv.-nek a közérdekű és a közérdekből nyilvános adatok megismerhetőségére vonatkozó szabályai a közpénzekkel való gazdálkodás átláthatóságát biztosítják. A törvényalkotó ezért a közfeladatot ellátó személyek és az államháztartás alrendszerébe tartozó valamely személlyel pénzügyi vagy üzleti kapcsolatot létesítő személyek/szervezetek számára is egyaránt kötelezettségeket fogalmaz meg.

Az adatszolgáltatásra kötelezettek körét az Infotv. a közfeladatot ellátó szerveken túlra tágítja. Az állami vagyonról szóló törvény pedig a közpénzek, az állami vagyon müködtetésének átláthatósága érdekében kiterjeszti az Infotv. információszabadságra vonatkozó rendelkezéseinek az alkalmazását az állami vagyonnal gazdálkodó vagy azzal rendelkező szervekre és személyekre, amikor kimondja, hogy ők az Infotv. szerinti közfeladatot ellátó szervnek vagy személynek minősülnek.

A közérdekű adatokra főszabályként a nyilvánosságelve vonatkozik. Ennek érvényesüléséhez szükséges, hogy az adatkezelő a közérdekű adatok megismerését biztosítsa. Kötelezettek általában az állami feladatot ellátó szervek. Mivel az Alaptörvény szerint a nyilvánosság előtti elszámolásra a közpénzekkel gazdálkodó minden szervezet köteles, az általuk kezelt közérdekű adatokhoz való hozzáférést - különösen erre irányuló igény esetén - a közfeladatot ellátó szerveken kívüli szervezetnek is biztosítania kell. Az Alaptörvényből következik tehát, hogy a közérdekű adatszolgáltatás kötelezettsége nem függvénye annak, hogy közérdekű adatot birtokló szervezet milyen szervtípusba tartozik, a közérdekű adatszolgáltatásra irányuló kötelezettséget önmagában megteremti az a tény, hogy a szervezet közérdekü adatot birtokol. Az Infotv. 2014-es módosítása alapján a közérdekből nyilvános adatokhoz való hozzáférést a nem közfeladatot ellátó természetes személyek, jogi személyek vagy jogi személyiséggel nem rendelkező szervezetek is biztosítani kötelesek akkor, ha az államháztartás alrendszerébe tartozó valamely személlyel pénzügyi vagy üzleti kapcsolatot létesítenek.

Az Infotv. a közérdekű és a közérdekből nyilvános adatok tekintetében egyaránt biztosítja az adatigénylés lehetőségét, az adatigény nem teljesítése esetében garantálja a bírósághoz fordulás lehetőségét. Az Infotv. azonban kifejezetten a „közfeladatot ellátó szervet” említi a per alpereseként. E fogalomhasználatot és a közérdekü 
adatigénylési per szabályait a jogalkotó nem igazította hozzá a régi Ptk.-ból az Infotv. rendelkezéseihez. Így a nem közfeladatot ellátó, tájékoztatásra kötelezett személyekkel és szervezetekkel szemben az Infotv.-ben foglalt általános rendelkezések alapján közérdekủ adatigénylési per megindításának nincs helye. Az Infotv. csak a törvényességi felügyeletet gyakorló szervhez történő fordulást teszi lehetővé, amely viszont az adatigény teljesítésének elrendelésére nem jogosult. Sőt: egyes, az adatigény teljesítésére egyébként köteles személyek (például: a természetes személyek) felett nincs is törvényességi felügyeletet gyakorló szerv.

Az Alaptörvény és az Infotv. rendelkezései alapján az adatnyilvánosság biztosítása alkotmányosan nem csupán a közfeladatot ellátó szerveket terheli. Az Alaptörvény általános jelleggel írja elő a közpénzekkel való gazdálkodás transzparenciáját. Az Alaptörvény garantálja a közérdekủ adatok megismerését, az Alkotmánybíróság gyakorlata szerint az információszabadság mint alapjog érvényesülése érdekében biztosítani kell a nyilvánosságkorlátozás feletti érdemi és hatékony bírói jogorvoslati lehetőséget. Az információszabadság mint alapjog védelméhez egyértelmüen hozzátartozik, hogy vélt vagy valós jogsértés esetén a jogosult bírósághoz fordulhat. A hatékony bírói jogvédelem biztosítása magában foglalja azt a követelményt, hogy az alapvető jog gyakorlására visszavezethető adatigény megalapozottságáról döntő - lényegében közvetlenül egy alapjog védelmében eljáró - bírói fórum adott esetben az adatigény teljesítését is ki tudja kényszeríteni: kötelező döntésével az adatkezelőt az adat kiadására rá tudja bírni. Az Alaptörvénnyel az a jogi szabályozás áll összhangban, amely garantálja a teljes körű és hatékony (az adatkiadásra való kötelezés lehetőségét is tartalmazó) bírói jogvédelmet.

Összefoglalásul: a közérdekű adatok megismeréséhez és terjesztéséhez való jog - összhangban az Alaptörvény közpénzek nyilvánosságára vonatkozó szabályával megköveteli, hogy az adatigény minden tájékoztatásra kötelezettet illetően bíróság előtt érvényesíthető, kikényszeríthető legyen. Ennek hiánya nem összeegyeztethető az Alaptörvénnyel. A törvényességi felügyeletet gyakorló szervhez fordulásnak a lehetősége - mivel a törvényességi felügyeleti eljárásban nincs helye az adat kiadására való kötelezésnek - nem tesz eleget e követelményeknek. Más jogérvényesítési lehetőség viszont jelenleg nem áll az adatigénylők rendelkezésére.

Az említett szabályozási hiány - az Infotv. 27. \$ (3a) bekezdése szerinti tájékoztatási kötelezettség bíróság előtti hatékony érvényesíthetőségének a hiánya a hatályos szabályozásban - a vizsgált esetben az Alaptörvény sérelmét idézi elő. Az alaptörvény-ellenes helyzet megszüntetése érdekében az Alkotmánybíróság mulasztással előidézett alaptörvény-ellenességet állapított meg, és felhívta a jogalkotót az Infotv. és az Alaptörvény rendelkezései közötti összhang megteremtésére, annak érdekében, hogy az adatigénylőknek a nem közfeladatot ellátó szerv tájékoztatási kötelezettségének nem teljesítése esetére biztosítsa a hatékony bírói jogvédelmet.

Az Infotv. támadott rendelkezése alaptörvény-ellenességének a megállapítására irányuló indítványt az Alkotmánybíróság elutasította, ugyanis a törvényességi felügyeletet gyakorló szerv eljárása kezdeményezésének a lehetősége önmagában nem 
tekinthető alapjog-korlátozó elöírásnak. Másrészt a rendelkezés megsemmisítése sem vezetne a közérdekű adatigénylési per előírásainak alkalmazhatóságára. Az alaptörvény-ellenességet nem az Infotv. 27. $\$$ (3b) bekezdése, hanem kifejezetten szabályozási hiátus okozta, csak ennek pótlásával tehető a szabályozás alaptörvénykonformmá.

\section{10/2020. (V. 28.) AB határozat - megváltozott munkaképességü személyek ellátásai}

Az Alkotmánybíróság e határozatában a szociális jogok védelmében mondott ki a jogszabály értelmezését segítő alkotmányos követelményt: a megváltozott munkaképességủek ellátásának megállapításánál a nem folyósított ellátás által keletkező biztosítási időt is figyelembe kell venni, amennyiben az EJEB konkrét egyedi ügyben Magyarországra kötelező jogerős döntésében azért állapítja meg az Egyezmény sérelmét, az EJEB jogerős döntését követően pedig a kérelmező ismételten kezdeményezi valamely ellátás megállapítását.

A Kúria az előtte folyamatban lévő, társadalombiztosítási határozat felülvizsgálata iránt indított eljárásokban az Alkotmánybírósághoz fordult, indítványozva, hogy az Alkotmánybíróság a megváltozott munkaképességű személyek ellátásairól és egyes törvények módosításáról szóló törvény (Mmtv.) egyes rendelkezései nemzetközi szerződésbe ütközését állapítsa meg. Az indítványozó szerint a támadott rendelkezés ellentétes az Emberi Jogok Európai Egyezménye (a továbbiakban: Egyezmény) Első Kiegészítő Jegyzőkönyv 1. cikkével.

Az alapügyek felperese az Emberi Jogok Európai Bírósága (EJEB) által eldöntött Nagy Béláné kontra Magyarország ügy \{[GC], (53080/13), 2016. december 13.\} kérelmezője. A kérelmező 2001-től rokkantsági nyugdíjban részesült, mivel betegségek miatt a munkaképességének $67 \%$-át elveszítette. A foglalkozással összefüggésben bekövetkezett egészségkárosodás megítélésére alkalmazott módszertanról szóló jogszabály megváltozott, az új módszertan szerint pedig a szakértő a kérelmezőnél 40\%-os rokkantságot állapított meg, amelynek következtében a hatóság megszüntette a rokkantsági nyugdíjra való jogosultságát. A kérelmező 2011-ben kezdeményezte rokkantságának felülvizsgálatát, a hatóság 50\%-os rokkantságot állapított meg, továbbá komplex rehabilitációt és rehabilitációs járadékra való jogosultságot javasolt a kérelmező számára.

A kérelmező kérelme alapján később ismét 50\%-os rokkantságot állapítottak meg. Ez a rokkantsági mérték elérte az állapotromlás azon szintjét, amely alapján a kérelmező az Mmtv. szerinti ellátásra vált volna jogosulttá, azonban a hatóság azt is megállapította, hogy a kérelmező nem rendelkezik az ellátás megállapításához szükséges, a kérelem benyújtását megelőző 5 évben 1095 nap biztosítási idővel. A szükséges biztosítási idő követelménye alól pedig az Mmtv. kizárólag abban az esetben engedett volna kivételt, amennyiben a kérelmező az Mmtv. hatálybalépését megelőző napján rokkantsági nyugdíjban vagy rehabilitációs járadékban részesült volna, amely kivétel alkalmazásának feltételei ugyancsak nem teljesültek. 
A rokkantsági ellátás iránti kérelem jogerős elutasítását követően a kérelmező az EJEB-hez fordult, amelynek Nagykamarája megállapította, hogy ugyan a rokkantsági ellátások Mmtv. szerinti átalakítása a közpénzek védelmével indokolható, a kérelmezőnek a konkrét ügyben mégis túlzott egyéni terhet kellett viselnie. A kérelmező ugyan folyamatosan együttmüködött a hatóságokkal, és összesen 23 év 71 nap szolgálati időt szerzett, a kérelmének benyújtását megelőző öt évben a szükséges 1095 nap biztosítási időt mégsem tudta igazolni, mert a rokkantsági nyugdíj megszủnését követő időszakban már nem minősült biztosítottnak. A Nagykamara ezért megállapította az Egyezmény megsértését, és 68 havi nem folyósított rokkantsági ellátásra tekintettel egyösszegủ vagyoni kártérítést ítélt meg.

Az EJEB döntése után a felperes a megváltozott munkaképességű személyek ellátása megállapítását kérte. A Járási Hivatal a kérelmet elutasította, mivel ugyan a kérelmező egészségi állapota alapján megváltozott munkaképességűnek minősül, azonban nem rendelkezik az Mmtv. szerint szükséges biztosítási idővel. A határozat ellen a felperes fellebbezésében arra hivatkozott, hogy az EJEB döntése alapján jogosult rokkantsági nyugdíjra. A másodfokon eljáró Kormányhivatal megállapította, hogy az EJEB ítélete nem változtat azon a tényen, hogy a megváltozott munkaképességü személyek ellátásának megállapításához valamennyi feltételnek egyszerre teljesülnie kell, a kérelmező azonban a szükséges biztosítási idővel nem rendelkezik. A határozat szerint az Mmtv. nem biztosít sem mérlegelési, sem pedig méltányossági jogkört az eljáró hatóság részére, így a jogosultsági feltételek hiányában nincs jogszabályi lehetőség az ellátás méltányosságból történő, kivételes megállapítására.

A kérelmező azonban éppen az egészségi állapota miatt nem tud dolgozni, így a törvény szerint szükséges biztosítási idő követelményét sem tudja utólag teljesíteni. A határozattal szemben ezért keresetet terjesztett elő. A Közigazgatási és Munkaügyi Bíróság a keresetet elutasította, mivel a határozat törvényes, a támadott határozatot kizárólag törvényességi szempontból vizsgálhatta felül, és méltányosságot nem gyakorolhat. Az ítélettel szemben a felperes felülvizsgálati kérelmet terjesztett elő, az ügyben eljáró Kúria pedig az Alkotmánybírósághoz fordult, a jogszabály nemzetközi szerződésbe ütközésének megállapítását és megsemmisítését kérte két folyamatban lévő perben.

2001-ben a rokkantsági nyugdíjra való jogosultság feltétele volt meghatározott mértékủ szolgálati idő igazolása, amit az alapügy felperese több mint 20 éven át tartó járulékfizetéssel megkérdőjelezhetetlenül teljesített. Az egészségi állapot értékelésére vonatkozó szabályozás megváltozása miatt a felperes egészségi állapotának százalékos mértéke kismértékben átmenetileg javult, de valódi egészségi állapota szignifikánsan nem változott meg. Ezen állapotjavulás eredményeként nem rendelkezett folyósított ellátással, így elesett az Mmtv. szerinti ellátások igénybevételének lehetőségétől, mert az Mmtv. nem biztosít arra lehetőséget, hogy az előírt időszakban biztosításban töltött időre vonatkozó feltétel vizsgálatától a jogalkalmazó szervek eltekintsenek, így annak alkalmazását a Kúria nem mellőzheti. 
A rendelkezés alkalmazása ugyanakkor a Kúria szerint döntését az Egyezmény Első Kiegészítő Jegyzőkönyv 1. cikkével és az Alaptörvénnyel ellentétessé tenné, annak eredményeként ugyanis ismételten bekövetkezik az EJEB döntésével egyszer már a kérelmező ügyében egyezménysértőnek minősített helyzet azáltal, hogy az alapügy felperese számára ezúttal sem állapítják meg az Mmtv. szerinti ellátást annak ellenére, hogy arra az egészségi állapota alapján jogosult lenne.

A Kúria utalt a 21/2018. (XI. 14.) AB határozatra is, amelyben az Alkotmánybíróság kimondta, hogy az a szabályozás, amely a megváltozott munkaképességű személyek ellátásainak rendszerét olyan módon alakítja át, hogy annak eredményeként az egyének az átalakítással túlzott terhet viselnek, ellentétes az Egyezmény Első Kiegészítő Jegyzőkönyv 1. cikkével, és túlzottnak tekinthető a teher akkor, ha a fogyatékossággal élő személyek tényleges fizikai állapotának kismértékű javulása, az egyéb körülmények szignifikáns változása nélkül az ellátás összegének állapotjavulásukat nyilvánvalóan aránytalan mértékben meghaladó, jelentős csökkenésével jár.

Az indítványokban megjelölt Nagy Béláné kontra Magyarország ügy kérelmezője azonos a bírói kezdeményezések alapjául szolgáló peres eljárások felperesével, amely egyezésre tekintettel az Alkotmánybíróság kifejezetten felhasználta az EJEB megállapításait.

Az Alkotmánybíróság a támadott rendelkezéseket megvizsgálta. Az Mmtv. szerinti ellátások jövedelempótló jellegü ellátások, azaz a megállapításuk akkor lehetséges, ha a kérelmező az állapota miatt keresőtevékenységet nem tud folytatni. Az ellátások egészségbiztosítási pénzbeli ellátásoknak minősülnek, ennek megfelelően csak azok számára állapíthatók meg, akik meghatározott idejű biztosítási idővel rendelkeznek.

Az ellátások folyósításának előfeltétele a biztosítási idő vizsgálata, és ez indokolt. Nem ellentétes az Egyezménnyel az Mmtv. azon rendelkezése, amely meghatározza, hogy mennyi biztosítási idő megszerzésével válik a kérelmező jogosulttá az Mmtv. szerinti ellátások valamelyikére. Ellenkezőleg: éppen a biztosítási idő megkövetelésével válnak az ellátások olyanná, mint amelyek az Egyezmény hatálya alá tartoznak. Az Alkotmánybíróság azt is kiemelte, hogy a támadott rendelkezés megsemmisítése az Mmtv. szerinti ellátásokat lényegében a biztosítási időtől függetlenül elérhetővé tenné, amely egyenesen az ellátások egészségbiztosítási jellegét szüntetné meg, és kifejezetten szembe menne a közpénzek védelmének EJEB által is elismert céljával. Ennek megfelelően az Alkotmánybíróság megállapította, hogy az Egyezményből az Mmtv. szerinti, az Egyezmény hatálya alá tartozó ellátások folyósításának feltételeire vonatkozóan az következik, hogy a részes államok nagy mérlegelési szabadsággal rendelkeznek e feltételek meghatározásának kérdésében. Önmagában az a szabályozás, amely az ellátás folyósításának feltételeként azt követeli meg, hogy a kérelem benyújtását megelőző időszak kétharmadára vonatkozóan tudjon a kérelmező biztosítási időt igazolni, nyilvánvalóan nem tekinthető e mérlegelési szabadság kereteit túllépő, észszerűtlen előírásnak, mert az egészségbiztosítási pénzbeli ellátásokat egyebek között éppen a korábbi biztosítási idő igazolásának megkövetelése különbözteti meg az alanyi jogon járó ellátásoktól. 
Mindezekre tekintettel az Alkotmánybíróság az Mmtv. támadott rendelkezései nemzetközi szerződésbe ütközésének megállapítására irányuló bírói kezdeményezést elutasította.

Az Alkotmánybíróság azt is megállapította, hogy amennyiben az Mmtv. vizsgált rendelkezéseit a bírói kezdeményezésekre okot adó ügyekben alkalmazzák, úgy ennek eredményeként az Mmtv. rendelkezéseinek megfelelően az alapügyek felperese számára az Mmtv. szerinti ellátások folyósítására nem kerülhet sor, amely döntés eredményét tekintve hasonló lenne ahhoz, mint amely alapján az EJEB a Nagy Béláné kontra Magyarország ügyben megállapította korábban Magyarország felelősségét az Egyezmény megsértése miatt. Mindez azt jelenti, hogy miközben az Mmtv. támadott rendelkezése önmagában nem ütközik az Egyezménybe, az adott rendelkezés egyes konkrét, egyedi ügyben történő alkalmazása az adott ügy egyedi körülményeire tekintettel kivételesen mégis az Egyezménnyel mint nemzetközi szerződéssel ellentétes eredményre vezethet.

Az Alaptörvény szerint Magyarország nemzetközi jogi kötelezettségeinek teljesítése érdekében biztosítja a nemzetközi jog és a magyar jog összhangját. Ha a vizsgált jogszabálynak van olyan értelmezése, amely az Alaptörvénnyel, illetőleg az Egyezménnyel mint nemzetközi szerződéssel összhangban áll, az Alkotmánybíróságnak a hatályos jog kíméletének elvéből kiindulva nem kell megsemmisítenie a támadott jogszabályi rendelkezést, ugyanakkor azt biztosítania kell, hogy a norma alkalmazása minden esetben az Alaptörvénnyel (jelen esetben az Egyezménnyel) összhangban álló eredményre vezessen. Az Alkotmánybíróság ezért megvizsgálta, hogy az Mmtv. rendelkezései értelmezhetők-e úgy, hogy azok még a jelen esetben is biztosíthassák az Egyezménnyel összhangban álló eredmény lehetőségét.

Az Alkotmánybíróság kiemelte: ha az ellátásra jogosult az Mmtv. szerinti ellátások valamelyikében részesül, akkor ez az időszak biztosítási időnek minősül. Abban az esetben, ha az EJEB konkrét egyedi ügyben született döntésével azért állapítja meg az Egyezmény megsértését, mert a kérelmező számára nem folyósították valamely, az Mmtv. szerinti, biztosítási időt is keletkeztető ellátást, tartalmilag egyben azt is megállapítja, hogy a kérelmező számára valamely, egyébként biztosítási időt is keletkeztető ellátást folyósítani kellett volna.

Az Alkotmánybíróság ezért az Egyezmény mint Magyarország által nemzetközi szerződéssel vállalt nemzetközi kötelezettség érvényesülése kötelezettségének az Alaptörvény Q) cikk (2) bekezdéséből fakadó biztosítása érdekében alkotmányos követelményként állapította meg, hogy az Mmtv. szerinti időtartam meghatározása során a nem folyósított ellátás által keletkező biztosítási időt is figyelembe kell venni, amennyiben az EJEB konkrét egyedi ügyben Magyarországra kötelező jogerős döntésében azért állapítja meg az Egyezmény sérelmét, mert a kérelmező számára valamely, biztosítási időt keletkeztető ellátást, amelyet folyósítani kellett volna, nem folyósítottak, az EJEB jogerős döntését követően pedig a kérelmező ismételten kezdeményezi valamely, az Mmtv. szerinti ellátás megállapítását. Az alkotmányos követelmény szerinti feltételek minden esetben az ügyben eljáró hatóságok, illetőleg bíróságok feladata. 